\title{
Instability of Cefpodoxime Proxetil Oral Suspension at Different Temperature Storage Conditions
}

\begin{abstract}
The advantages of oral dosage form over other dosage forms are responsible for its popularity which includes its ease of administration, patient compliance and stability of the formulation. This study compared the stability of three Cefpodoxime proxetil products available in Nigeria market at fridge temperatures $\left(2-8^{\circ} \mathrm{C}\right)$, room temperature $\left(25^{\circ} \mathrm{C}\right)$ and elevated temperature $\left(42^{\circ} \mathrm{C}\right)$. Flow properties, rheological and the physicochemical parameters of both powder and reconstituted powder were used to evaluate the stability of different brands of Cefpodoxime proxetil available in Nigeria. This study shows that the potencies of all the reconstituted samples stored at $25{ }^{\circ} \mathrm{C}$ were within the specified standard range within the evaluating period of 90 days, while the potencies of those samples under refrigerated condition were within the specified standard range within the evaluating period of 14 days. For powdered samples, there was a considerable loss of potencies $(<85 \%)$ at elevated temperature $\left(42^{\circ} \mathrm{C}\right)$ in all the samples after day 60 . Physicochemical evaluation also agrees with the outcome of the drug assay for all the samples except Tambac ${ }^{\circledR}$ which deviated from specification as from day 14 . The study therefore emphasizes the need for the storage of both reconstituted and un-reconstituted suspensions at refrigerated and temperature less than $25^{\circ} \mathrm{C}$.
\end{abstract}

Keywords: Cefpodoxime; Stability; Reconstitution; Suspensions

\section{Introduction}

Drugs like living organisms do react to the external stimuli such as heat, humidity, light, microbial agents and dust. In many of such cases, the reactions can only lead to physical changes such as discolouration of the product, change in taste and offensive odour. The fact, that drug products have the potential to degrade on storage has been known for ages. This instability can sometimes be so acute as to result in not only therapeutic failure, which is lacking in acceptance safety, efficacy or product acceptability within short time-in extreme cases in only a few days but also cause adverse effects on the patient's health [1].

However, there is a good reason to believe that pharmaceutical products in the proper drug distribution channel are often not always stored according to the manufacturers label instruction [2]. Thus, the need to establish the stability of drug products most especially when the product gets to the end user. A product with stability issue is most likely going to fail both therapeutic and pharmaceutical tests. It is therefore imperative to make stability studies a prerequisite for the acceptance and approval of any pharmaceutical product by the drug regulatory agency.

Stability of a pharmaceutical product may be defined as the capability of a particular formulation in a specific container/closure system to remain within its physical, chemical, microbiological,

\section{Journal of}

Pharmaceutics \& Pharmacology

\author{
Abayomi Omotoso Ebenezer*, Chinaka Chioma \\ and Iweka Marvin Omoegbe
}

Department of Pharmaceutical and Medicinal Chemistry, University of Port Harcourt, Nigeria

Address for Correspondence

Abayomi Omotoso Ebenezer, Department of Pharmaceutical and Medicinal Chemistry, Faculty of Pharmaceutical Sciences, University of Port Harcourt, Nigeria, E-mail: abayomi.omotoso@uniport.edu.ng

Submission: 05 December, 2017

Accepted: 29 December, 2017

Published: 05 January, 2018

Copyright: (๑) 2017 Ebenezer AO, et al. This is an open access article distributed under the Creative Commons Attribution License, which permits unrestricted use, distribution, and reproduction in any medium, provided the original work is properly cited.

toxicological, protective and informational specifications [3]. Although there are exceptions, $90 \%$ of the labeled potency is generally recognized as the maximum acceptable potency level [4]. Thus stability study maintains the product quality, safety and efficacy throughout the product shelf-life [3]. The stability of pharmaceutical products depends on many factors, such as stability of the active pharmaceutical ingredient, the potential interaction between the active ingredient and the excipient, the dosage form, the storage condition, handling and length of time between manufacture and final usage. Although factors like environmental influence like light, moisture and heat are important in stability study of pharmaceutical products [5].

Dry powders for oral suspension are powder mixtures which require reconstitution at the time of administration mostly for paediatric use [6]. We therefore investigated the effect of temperature on the physicochemical characteristics of some oral reconstitutable Cefpodoxime proxetil dry powder and suspension available in Nigerian pharmaceutical market and also to be able to select and recommend the best from the series of possible choices. This study specifically aimed to achieve these objectives by applying a simple, accurate and less time consuming validated UV spectroscopic method for the quantification of Cefpodoxime proxetil in samples subject to variable storage conditions, thus their physicochemical stability assessment over a period of time.

\section{Materials and Methods}

\section{Materials}

The pure sample Cefpodoxime proxetil was obtained from Qingdao Tai Hong Da Chemical Co., Ltd. China. Three brands of Cefpodoxime ( $40 \mathrm{mg} / 5 \mathrm{~mL}, 50 \mathrm{mg} / 5 \mathrm{mLl}$ and $40 \mathrm{mg} / 5 \mathrm{mLl}$ ) containing $800 \mathrm{mg}, 1000 \mathrm{mg}$ and $800 \mathrm{mg}$ respectively for reconstitution in water for oral use were used in this study. The brands used (A: Innovator product, B: Generic product-Indian origin, and C: Generic productIndian origin). The samples were purchased from reputable and registered pharmacies and were within the stated expiry dates as at 
Citation: Ebenezer TO, Chioma C, Omoegbe IM. Instability of Cefpodoxime Proxetil Oral Suspension at Different Temperature Storage Conditions. J Pharmaceu Pharmacol. 2017;5(1): 6 .

ISSN: $2327-204 X$

Table 1: $R$, values for the non-reconstituted samples on days $0,30,60$ and 90 (Mobile phase; Chloroform (4): Methanol (2): Toluene (4)).

\begin{tabular}{|l|c|}
\hline \multicolumn{1}{|c|}{ Spotted Samples } & $\mathbf{R}_{\mathbf{f}}$ \\
\hline Cefpodoxime(a) & $1=0.64$ \\
\hline A & $2=0.64$ \\
\hline B & $3=0.63$ \\
\hline C & $4=0.67$ \\
\hline
\end{tabular}

Table 2: $R_{f}$ values for the reconstituted samples on days 60 and 90 (Mobile phase; Methanol (10): Ammonium hydroxide (0.1)).

\begin{tabular}{|l|c|c|}
\hline \multicolumn{1}{|c|}{ Spotted Samples } & $\mathbf{R}_{\mathbf{f}}$ & $\mathbf{R}_{\mathbf{f}}$ \\
\hline Cefpodoxime & $1=0.54$ & - \\
\hline A & $2=0.57$ & $5=0.93$ \\
\hline B & $3=0.55$ & $6=0.93$ \\
\hline C & $4=0.56$ & $7=0.93$ \\
\hline
\end{tabular}

the time of this study.

\section{Instrument/Reagents}

All other reagents used were of analytical grade (JHD, China and Sigma-Aldrich, Germany). UV-VIS Spectrophotometer (Single beam-295), Ostwald U-tube Viscometer (England), Aluminium plated silica gel plates, Pycnometer (Pyrex', England), pH meter (PEC Medical, USA).

\section{Methods}

\section{Protocol}

The dry powder blend (Product A, B and C) ready for reconstitution and the prepared suspension $(100 \mathrm{~mL})$ were individually subjected to short term stability study for a period of three months as per ICH guidelines [7]. Six (6) bottles of each brand were used for the study consisting of; reconstituted ( 3 bottles) and un-reconstituted ( 3 bottles). The variable storage conditions commented were; refrigerator condition $\left(2{ }^{\circ} \mathrm{C}-8{ }^{\circ} \mathrm{C} / 40 \% \mathrm{RH}\right)$, room temperature $(25$ $\left.{ }^{\circ} \mathrm{C} / 60 \% \mathrm{RH}\right)$ and elevated temperature conditions ( $\left.42{ }^{\circ} \mathrm{C} / 75 \% \mathrm{RH}\right)$. For each of the environmental conditions stated above one sample each of the reconstituted and un-reconstituted was used.

\section{Preparation of stock solution}

Stock solution of Cefpodoxime $(100 \mu \mathrm{g} / \mathrm{mL})$ was prepared by dissolving accurately weighed $10 \mathrm{mg}$ pure sample of Cefpodoxime proxetil in $100 \mathrm{~mL}$ of methanol.

\section{Determination of wavelength of maximum absorption}

Scanning for wavelength of maximum absorption was carried out using Stock solution of pure Cefpodoxime proxetil using UV/VIS Spectrophotometer within the range of $200-800 \mathrm{~nm}$.

\section{Preparation of working solution}

The prepared stock solution $(100 \mu \mathrm{g} / \mathrm{mL})$ was further diluted with methanol to get working standard solutions of $4-24 \mu \mathrm{g} / \mathrm{mL}$ (Table 1).

\section{Assay of Cefpodoxime in the Samples}

Non-reconstituted samples
The weight of powdered sample of Product " $A$ " equivalent to 10 mg Cefpodoxime was accurately transferred to a volumetric flask containing $70 \mathrm{~mL}$ of methanol, sonicated for $15 \mathrm{~min}$ and then filtered. The residue was washed with $2 \times 10 \mathrm{~mL}$ portion of methanol and made up to $100 \mathrm{~mL}$ with methanol $(100 \mu \mathrm{g} / \mathrm{mL})$. The absorbances of each of the resulting solution were read at $281 \mathrm{~nm}$ in triplicates. The above procedure was repeated for the other two brand sat day $0,30,60$ and 90 under the various storage conditions $[8,9]$.

\section{Reconstituted samples}

Samples of Product "A" was reconstituted with portable water according to the instruction of the manufacturer, shaken and $5 \mathrm{~mL}$ of the suspension so produced was transferred into a $50 \mathrm{~mL}$ volumetric flask containing $25 \mathrm{~mL}$ of methanol, shaken and made up to volume before sonication and filtration. The filtrate $(5 \mathrm{~mL})$ was transferred into a $50 \mathrm{~mL}$ volumetric flask and made up to the $50 \mathrm{~mL}$ mark. The absorbance of the resulting solution was read at $281 \mathrm{~nm}$ and their corresponding concentration $(\mu \mathrm{g} / \mathrm{mL})$ determined by using the BeerLambert's plot. The above procedure was repeated for Products $B$ and $\mathrm{C}$ at days $0,7,14,30,60$ and 90 at the different stated storage conditions.

\section{Determination of $\mathbf{p H}$}

The $\mathrm{pH}$ meter was calibrated before each measurement was taken after transferring the sample into a beaker and the probe of the meter inserted into the samples. The $\mathrm{pH}$ of the reconstituted suspension was read on the screen of the meter for all the samples at days $0,7,14,30$, 60 and 90 at their various storage conditions.

\section{Moisture content determination}

The moisture content of the dry powders were determined by weighing $3.0 \mathrm{~g}$ of powder into a pre-weighed ceramic crucible which was then placed in an oven set at $105^{\circ} \mathrm{C}$ for $1 \mathrm{hr}$, cooled, weighed and placed again in the oven until a constant weight was achieved. This procedure was repeated for the other samples at day $0,30,60$ and 90 at their respective storage conditions. The moisture content was calculated according to the equation below;

$$
\% \text { Moisture content }=\frac{\text { Weight of the sample before heating-Weight of the sample after heating }}{\text { Weight of the sample before heating }} \times 100
$$

\section{Thin layer chromatography (TLC)}

The reconstituted samples were analyzed for degradation products by TLC on days $0,30,60$ and 90 using both mixtures of Chloroform: Methanol: Toluene $(4: 2: 4 \mathrm{v} / \mathrm{v} / \mathrm{v})$ and Methanol: Ammonium Hydroxide (10:0.1 v/v) separately as the mobile phase with aluminium backed Silica gel $60 \mathrm{~F}_{254}$ TLC plate serving as the stationary phase [10].

\section{Physical properties determination}

The samples (reconstituted and non-reconstituted) were evaluated for physical stability by determining the aesthetic appeal (odour, taste, colour and texture), sedimentation volume, ease of re-dispersion, viscosity, particle size, flow rate, angle of repose, bulk density, tapped density, compressibility index and Hausner's ratio as applicable. All parameters were performed in triplicate. 
Citation: Ebenezer TO, Chioma C, Omoegbe IM. Instability of Cefpodoxime Proxetil Oral Suspension at Different Temperature Storage Conditions. J Pharmaceu Pharmacol. 2017;5(1): 6

\section{ISSN: 2327-204X}

Table 3: Physico-chemical parameters at refrigerator temperature $\left(2{ }^{\circ} \mathrm{C}-8{ }^{\circ} \mathrm{C} / 40 \% \mathrm{Rh}\right)$.

\begin{tabular}{|c|c|c|c|c|c|c|c|c|c|c|c|c|c|c|c|c|c|c|}
\hline \multirow[t]{2}{*}{ Parameters } & \multicolumn{6}{|c|}{ Product A } & \multicolumn{6}{|c|}{ Product B } & \multicolumn{6}{|c|}{ Product C } \\
\hline & Day 0 & Day 7 & Day 14 & Day 30 & Day 60 & Day 90 & Day 0 & Day 7 & $\begin{array}{c}\text { Day } \\
14\end{array}$ & $\begin{array}{c}\text { Day } \\
30\end{array}$ & $\begin{array}{c}\text { Day } \\
60\end{array}$ & $\begin{array}{l}\text { Day } \\
90\end{array}$ & Day 0 & Day 7 & $\begin{array}{c}\text { Day } \\
14\end{array}$ & Day 30 & Day 60 & Day 90 \\
\hline $\begin{array}{l}\% \text { of label } \\
\text { claim (non- } \\
\text { reconstituted) }\end{array}$ & 102.88 & - & - & 101.25 & 98.75 & 92.5 & 98.1 & - & - & 97 & 93 & 89 & 101.75 & - & - & 101.25 & 97.5 & 97.5 \\
\hline $\begin{array}{l}\% \text { of label claim } \\
\text { (reconstituted) }\end{array}$ & 102.36 & 102.5 & 101.25 & 88.75 & 111.25 & 118.75 & 99 & 98 & 95 & 88 & 112 & 122 & 101.13 & 101.25 & 97.5 & 87.5 & 113.8 & 121.25 \\
\hline $\mathrm{pH}$ & 6.33 & 5 & 5 & 4 & 3 & 3 & 5.76 & 5 & 5 & 4 & 3 & 2 & 6.33 & 5 & 5 & 3 & 3 & 3 \\
\hline $\begin{array}{l}\% \text { moisture } \\
\text { content }(\% w / w)\end{array}$ & 2.33 & - & - & 23 & 15 & 14 & 1.33 & - & - & 30.67 & 13 & 13.67 & 0.67 & - & - & 26.67 & 16 & 20.2 \\
\hline $\begin{array}{l}\text { Powders flow } \\
\text { rate }(\mathrm{g} / \mathrm{sec})\end{array}$ & 28.01 & - & - & 43.48 & 22.73 & 21.24 & 22.22 & - & - & 37.04 & 22.39 & 20.21 & 37.45 & - & - & 43.48 & 24.59 & 23.44 \\
\hline $\begin{array}{l}\text { Angle of } \\
\text { repose }\left({ }^{\circ}\right)\end{array}$ & 36.03 & - & - & 33.25 & 29.28 & 25.15 & 34.44 & - & - & 33.11 & 29.97 & 23.45 & 34.14 & - & - & 36.7 & 29.28 & 23.45 \\
\hline $\begin{array}{l}\text { Viscosity of } \\
\text { reconstituted } \\
\text { samples }(c p)\end{array}$ & 70.58 & 89.61 & 100.49 & 82.75 & 73.36 & 59.88 & 38.42 & 16.99 & 18.11 & 18.92 & 23.21 & 20.39 & 24.24 & 29.01 & 30.5 & 33.81 & 50.12 & 62.67 \\
\hline $\begin{array}{l}\text { Bulk density ( } g / \\
\mathrm{mL})\end{array}$ & 0.5 & - & - & 0.48 & 0.63 & 0.63 & 0.76 & - & - & 0.83 & 0.74 & 0.77 & 0.69 & - & - & 0.74 & 0.91 & 0.95 \\
\hline $\begin{array}{l}\text { Tapped density } \\
(\mathrm{g} / \mathrm{mL})\end{array}$ & 0.59 & - & - & 0.59 & 0.71 & 0.77 & 0.91 & - & - & 1 & 0.77 & 0.83 & 0.87 & - & - & 0.77 & 1 & 1 \\
\hline $\begin{array}{l}\text { Compressibility } \\
\text { index }(\mathrm{Cl}) \%\end{array}$ & 15.25 & - & - & 18.64 & 11.27 & 18.18 & 16.48 & - & - & 17 & 3.9 & 7.23 & 20.69 & - & - & 3.9 & 9 & 5 \\
\hline $\begin{array}{l}\text { Hausner's } \\
\text { ratio(HR) }\end{array}$ & 1.18 & - & - & 1.23 & 1.13 & 1.22 & 1.2 & - & - & 1.21 & 1.04 & 1.08 & 1.26 & - & - & 1.04 & 1.1 & 1.05 \\
\hline
\end{tabular}

Table 4: Physico-chemical parameters at room temperature $\left(25^{\circ} \mathrm{C} / 60 \% \mathrm{Rh}\right)$.

\begin{tabular}{|c|c|c|c|c|c|c|c|c|c|c|c|c|c|c|c|c|c|c|}
\hline \multirow[t]{2}{*}{ Parameters } & \multicolumn{6}{|c|}{ Product A } & \multicolumn{6}{|c|}{ Product B } & \multicolumn{6}{|c|}{ Product C } \\
\hline & Day 0 & Day 7 & $\begin{array}{c}\text { Day } \\
14\end{array}$ & Day 30 & Day 60 & Day 90 & Day 0 & Day 7 & $\begin{array}{c}\text { Day } \\
14\end{array}$ & Day 30 & $\begin{array}{l}\text { Day } \\
60\end{array}$ & Day 90 & Day 0 & Day 7 & Day 14 & $\begin{array}{l}\text { Day } \\
30\end{array}$ & $\begin{array}{c}\text { Day } \\
60\end{array}$ & Day 90 \\
\hline $\begin{array}{l}\text { \% label } \\
\text { claim (non- } \\
\text { reconstituted) }\end{array}$ & 102.88 & - & - & 100.75 & 101.25 & 97.5 & 98.1 & - & - & 97 & 97 & 95 & 101.75 & - & - & 101 & 96.25 & 95 \\
\hline $\begin{array}{l}\text { \% label claim ( } \\
\text { reconstituted) }\end{array}$ & 102.36 & 101.25 & 97.5 & 83.75 & 110 & 121.25 & 99 & 97 & 94 & 71 & 118 & 121 & 101.13 & 98.75 & 92.5 & 77.5 & 116.25 & 110 \\
\hline $\mathrm{pH}$ & 6.33 & 5.5 & 4 & 3 & 3 & 3 & 5.67 & 5.5 & 4 & 3 & 3 & 3 & 6.33 & 5.5 & 4 & 3 & 3 & 3 \\
\hline $\begin{array}{l}\% \text { moisture } \\
\text { content }(\% w / w)\end{array}$ & 2.33 & - & - & 10.33 & 11 & 8.67 & 1.33 & - & - & 6.67 & 6.67 & 6.1 & 0.67 & - & - & 3.33 & 4.33 & 7.33 \\
\hline $\begin{array}{l}\text { Powders flow } \\
\text { rate (g/sec) }\end{array}$ & 28.01 & - & - & 31.25 & 26.32 & 28.4 & 22.22 & - & - & 21.74 & 25.42 & 21.07 & 37.45 & - & - & 38.46 & 23.08 & 30.5 \\
\hline $\begin{array}{l}\text { Angle of } \\
\text { repose ( () }\end{array}$ & 36.03 & - & - & 40.4 & 31.48 & 25.8 & 34.44 & - & - & 33.99 & 27.55 & 26.77 & 34.14 & - & - & 36.87 & 28.61 & 24.42 \\
\hline $\begin{array}{l}\text { Viscosity of } \\
\text { reconstituted } \\
\text { samples (cp) }\end{array}$ & 70.58 & 70.6 & 35.78 & 24.17 & 17.53 & 15.98 & 38.42 & 15.42 & 13.74 & 20.52 & 23.56 & 22.77 & 24.24 & 37.24 & 38.83 & 114.31 & - & - \\
\hline $\begin{array}{l}\text { Bulk density } \\
(\mathrm{g} / \mathrm{mL})\end{array}$ & 0.5 & - & - & 0.5 & 0.67 & 0.74 & 0.76 & - & - & 0.83 & 0.83 & 0.83 & 0.69 & - & - & 0.83 & 0.91 & 0.74 \\
\hline $\begin{array}{l}\text { Tapped density } \\
(\mathrm{g} / \mathrm{mL})\end{array}$ & 0.59 & - & - & 0.59 & 0.77 & 1 & 0.91 & - & - & 1 & 0.91 & 0.91 & 0.87 & - & - & 0.91 & 1 & 0.95 \\
\hline $\begin{array}{l}\text { Compressibility } \\
\text { index }(\mathrm{Cl}) \%\end{array}$ & 15.25 & - & - & 15.25 & 12.99 & 26 & 16.48 & - & - & 17 & 8.79 & 8.79 & 20.69 & - & - & 8.79 & 9 & 22.11 \\
\hline $\begin{array}{l}\text { Hausner's ratio } \\
\text { (HR) }\end{array}$ & 1.18 & - & - & 1.18 & 1.15 & 1.35 & 1.2 & - & - & 1.21 & 1.09 & 1.09 & 1.26 & - & - & 1.09 & 1.1 & 1.05 \\
\hline
\end{tabular}

\section{The aesthetic appeal}

The colour, odour, taste and texture were randomly determined.

\section{Particle size determination}

The average particle size of the formulation was examined using the nest of sieve method. The sieves were arranged in descending order of their aperture size, with the sieve of largest aperture on top. $5.0 \mathrm{~g}$ of the powder for reconstitution was placed on the upper sieve and the sieves are supported through on a collecting pan at the bottom. The sieves with the powders were subjected to mechanical vibration for $5 \mathrm{~min}$. After which the quantity of the powder retained by each of the sieves were determined and the average particle size diameter $\left(\mathrm{D}_{\text {ave }}.\right)$ calculated using; 
Citation: Ebenezer TO, Chioma C, Omoegbe IM. Instability of Cefpodoxime Proxetil Oral Suspension at Different Temperature Storage Conditions. J Pharmaceu Pharmacol. 2017;5(1): 6

ISSN: $2327-204 X$

Table 5: Physico-chemical parameters at elevated temperature $\left(42^{\circ} \mathrm{C} / 75 \% \mathrm{Rh}\right)$.

\begin{tabular}{|c|c|c|c|c|c|c|c|c|c|c|c|c|c|c|c|c|c|c|}
\hline \multirow[t]{2}{*}{ Parameters } & \multicolumn{6}{|c|}{ Product A } & \multicolumn{6}{|c|}{ Product B } & \multicolumn{6}{|c|}{ Product C } \\
\hline & Day 0 & Day 7 & $\begin{array}{c}\text { Day } \\
14\end{array}$ & $\begin{array}{c}\text { Day } \\
30\end{array}$ & $\begin{array}{c}\text { Day } \\
60\end{array}$ & $\begin{array}{c}\text { Day } \\
90\end{array}$ & Day 0 & Day 7 & $\begin{array}{c}\text { Day } \\
14\end{array}$ & $\begin{array}{c}\text { Day } \\
30\end{array}$ & Day 60 & Day 90 & Day 0 & Day 7 & $\begin{array}{c}\text { Day } \\
14\end{array}$ & Day 30 & $\begin{array}{c}\text { Day } \\
60\end{array}$ & Day 90 \\
\hline $\begin{array}{l}\% \text { label } \\
\text { claim (non- } \\
\text { reconstituted) }\end{array}$ & 102.88 & - & - & 97.5 & 88.75 & 85 & 98.1 & - & - & 89 & 78 & 72 & 101.75 & - & - & 96.25 & 88.75 & 73.75 \\
\hline $\begin{array}{l}\text { \% label claim } \\
\text { (reconstituted) }\end{array}$ & 102.36 & 98.75 & 92.5 & 76.25 & 113.75 & 131.25 & 99 & 95 & 91 & 72 & 120 & 132 & 101.13 & 100 & 90 & 70 & 115 & 132.5 \\
\hline $\mathrm{pH}$ & 6.33 & 6 & 4 & 4 & 3 & 3 & 5.67 & 6 & 3 & 3 & 3 & 2 & 6.33 & 6 & 3 & 4 & 3 & 2 \\
\hline $\begin{array}{l}\% \text { moisture } \\
\text { content }(\% w / w)\end{array}$ & 2.33 & - & - & 2 & 10 & 13 & 1.33 & - & - & 2.5 & 8.5 & 9.67 & 0.67 & - & - & 1.33 & 6.67 & 7.33 \\
\hline $\begin{array}{l}\text { Powders flow } \\
\text { rate }(\mathrm{g} / \mathrm{sec})\end{array}$ & 28.01 & - & - & 43.48 & 20.83 & 24.67 & 22.22 & - & - & 37 & 14.71 & 22.45 & 37.45 & - & - & 46.5 & 25 & 28.44 \\
\hline $\begin{array}{l}\text { Angle of } \\
\text { repose }\left({ }^{\circ}\right)\end{array}$ & 36.03 & - & - & 36.36 & 26.95 & 22.4 & 34.44 & - & - & 35.86 & 26.19 & 21.58 & 34.14 & - & - & 36.03 & 26.95 & 22.46 \\
\hline $\begin{array}{l}\text { Viscosity of } \\
\text { reconstituted } \\
\text { samples }(c p)\end{array}$ & 70.58 & 67.89 & 42.8 & 25.59 & 11.81 & 10.89 & 38.42 & 14.19 & 12.69 & 21.69 & 25.99 & 28.75 & 24.24 & 39.98 & 40.59 & 150.52 & - & - \\
\hline $\begin{array}{l}\text { Bulk density } \\
(\mathrm{g} / \mathrm{mL})\end{array}$ & 0.5 & - & - & 0.48 & 0.63 & 0.83 & 0.76 & - & - & 0.83 & 0.71 & 0.71 & 0.69 & - & - & 0.71 & 0.91 & 0.65 \\
\hline $\begin{array}{l}\text { Tapped density } \\
\text { (g/mL) }\end{array}$ & 0.59 & - & - & 0.61 & 0.77 & 0.91 & 0.91 & - & - & 1 & 0.83 & 0.83 & 0.87 & - & - & 0.91 & 1 & 0.95 \\
\hline $\begin{array}{l}\text { Compressibility } \\
\text { index }(\mathrm{Cl}) \%\end{array}$ & 15.25 & - & - & 21.13 & 18.18 & 8.79 & 16.48 & - & - & 17 & 14.46 & 14.46 & 20.69 & - & - & 14.46 & 9 & 12.16 \\
\hline $\begin{array}{l}\text { Hausner's ratio } \\
\text { (HR) }\end{array}$ & 1.18 & - & - & 1.27 & 1.22 & 1.2 & 1.2 & - & - & 1.21 & 1.17 & 1.17 & 1.26 & - & - & 1.17 & 1.1 & 1.14 \\
\hline
\end{tabular}

\section{$\mathbf{D}_{\text {ave }}=\frac{\sum[(\% \text { retained }) \times(\text { average sieve aperature in pairs })]}{100}$}

\section{Angle of repose determination}

The funnel exit orifice was placed at a height (h) of $2.0 \mathrm{~cm}$ above the horizontal surface the powder under consideration was poured into the funnel gently until the tip of the powder heap formed touch the tip of the orifice. The diameter (D) of the formed powder heap base was obtained. The angle of repose $(\theta)$ was determined using the equation;

$$
\theta=\tanh ^{-1}(2 \mathrm{~h} / \mathrm{D})
$$

These procedures were repeated for the other samples at day 0,30 , 60 and 90 at their respective storage conditions

\section{Flow rate determination}

A $10.0 \mathrm{~g}$ of the powder was placed in a plastic funnel held in position by a retort stand with its exit orifice closed and $10.0 \mathrm{~cm}$ from the horizontal surface. The time for $10.0 \mathrm{~g}$ of the powder to flow from the funnel down to horizontal surface after opening the exit orifice was determined using a stopwatch. The flow rate in weight per unit time $[\mathrm{W}(\mathrm{g}) / \mathrm{t}(\mathrm{secs})]$ was obtained. These procedures were repeated for the other samples at day 0, 30, 60 and 90 at their respective storage conditions.

\section{Bulk and tapped densities determination}

The method adopted in brief: A 5.0 g quantity of the powdered samples were placed in clean and dry $25 \mathrm{~mL}$ stoppered measuring cylinder, the volume $\left(\mathrm{V}_{\mathrm{o}}\right)$ occupied by each of the samples without tapping was determined. After 250 taps the volumes $\left(\mathrm{V}_{250}\right)$ occupied were determined. The bulk and tap densities were calculated as the ratio of weight to volume $\left(\mathrm{m} / \mathrm{V}_{\mathrm{o}}\right.$ and $\mathrm{m} / \mathrm{V}_{250}$ respectively). This procedure was carried out on all the different samples at days 0,30 , 60 and 90 at their respective storage conditions [11].

\section{Compressibility index and Hausner's ratio determination}

The Carr's compressibility index and Hausner's ratio were determined from the values of the bulk and tapped densities results obtained above using the equations below:

$$
\text { Carr's Index }(\mathrm{CI} \%)=\frac{\text { Tapped density }- \text { bulk density } \times 100}{\text { Tapped density }}
$$

$$
\text { Hausner's ratio }(\mathrm{HR})=\frac{\text { Tapped density }}{\text { Bulk density }}
$$

\section{Sedimentation volume and redispersibility}

The reconstituted suspension sedimentation volume and redispersibilty were determined thus; $5.0 \mathrm{~g}$ quantity of dry powder was poured into a $50 \mathrm{~mL}$ stoppered graduated measuring cylinder, water was added to mark to make a suspension that was dispersed thoroughly by tumbling the stoppered measuring cylinder up and down three times. The suspension was allowed to settle for three minutes and the volume of sediment $\left(\mathrm{H}_{\mathrm{o}}\right)$ noted. This was kept undisturbed for 14 days. The volume of sediment at 0 day, on $7^{\text {th }}$ and $14^{\text {th }}$ day $\left(\mathrm{H}_{\mathrm{u}}\right)$ was noted [12].

\section{Viscosity determination}

The viscosity of the reconstituted suspension was carried out using 
Table 6: Particle size determinations. Weight of powder used=5.0 g.

\begin{tabular}{|l|r|r|}
\hline \multicolumn{2}{|l|}{ Product } & Powders diameter $(\mu \mathrm{m})$ \\
\hline 1 & A & $14.38 \pm 1.2$ \\
\hline 2 & B & $19.52 \pm 2.3$ \\
\hline 3 & C & $14.62 \pm 1.4$ \\
\hline
\end{tabular}

an Ostwald U-tube viscometer at $25^{\circ} \mathrm{C}$. The reconstituted suspension was passed through the capillary arm of the viscometer, and the time required for the reconstituted suspension to pass between the upper and lower marks of the sample reservoir under gravity was compared with that of water. The viscosity of the reconstituted suspensions were determined using the equation;

$$
n_{1} / n_{2}=\sigma_{1} t_{1} / \sigma_{2} t_{2}
$$

Where: $\mathrm{n}_{1}=$ the viscosity of standard liquid; $\mathrm{n}_{2}=$ the viscosity of the reconstituted suspension; $t_{1}=$ flow time of water; $t_{2}=$ flow time of reconstituted suspension; $\sigma_{1}=$ the density of water and $\sigma_{2}=$ the density of the reconstituted suspension.

\section{Stability studies}

Stability studies were carried on the reconstituted and nonreconstituted suspension to assess their physical and chemical stabilities. The conditions for this study were chosen to simulate conditions which may influence the efficacy of Cefpodoxime suspension. Samples were stored in a fridge temperature $\left(2-8{ }^{\circ} \mathrm{C}\right)$, room temperature $\left(25{ }^{\circ} \mathrm{C}\right)$ and at elevated temperature $\left(42{ }^{\circ} \mathrm{C}\right)$ for a period of 90 days. Samples were withdrawn and analyzed for Cefpodoxime content, $\mathrm{pH}$, moisture content, particle size, angle of repose, flow rate, bulk and tapped density, drug content, sedimentation rate and volume, redispersibility and viscosity at a predetermined time intervals of $0,7,14,30,60$ and 90days [13]. The drug content assay was carried out using a UV-Vis validated method.

\section{Results and Discussion}

The primary reason why drugs are formulated as a suspension for reconstitution is inadequate chemical stability of the drug in aqueous vehicle [14]. In this study we investigated the effect of temperature on the physicochemical characteristics of some brands of oral reconstitutable Cefpodoxime proxetil in order to determine their stability profile. All the samples were within the expiry period and registered with appropriate drug regulatory agency in Nigeria. The colours of the unreconstituted product varies from off white to cream colour (sample "A") and yellow to brown (sample "B") in spite of the fact that sample " $C$ " maintaining its cream colour all through the duration of the study. The colours of individual sample depend on other formulation excipients. The reconstituted samples were banana flavoured, sweet with smooth texture. Chemical stability was analyzed through the drug content assay and by chromatography for possible degradation product of active drug (Cefpodoxime proxetil). The percentage of the labelled claim of the non-reconstituted samples decreased with time, across the different samples and at different storage conditions. Product "B" had the least percentage content across all storage conditions used. The drug content of samples in the refrigerator were within the USP specification for the duration of the study, except Product "B" whose drug content could not meet the specification on day 90 at room temperature [15]. Degradation of Cefpodoxime occurs either acidic, alkaline, oxidative, photolytic stabilities or combination thereof, but in this study as a result of the type of dissolution medium and the ester functional group present in the drug one is tempted to say hydrolysis must have play an important role in the degradation of Cefpodoxime proxetil [16]. The decrease in drug content of the samples as the sample ages for the non-reconstituted samples were reversed on day 60 , across all brands and storage conditions. The chromatographic analysis of the reconstituted products showed two distinct retention factor values on days 60 and 90 (Tables 1 and 2). The implication of this is that before/on day 60 another product (possibly the degradation product) has been formed which possibly might have a similar wavelength of maximum absorption close to that of the pure Cefpodoxime proxetil, thereby increasing the absorbance value obtained and therefore the corresponding increase in the calculated amount of the Cefpodoxime present in the samples (Further research is ongoing in our laboratory to characterize the product that gave the second $\mathrm{R}_{\mathrm{f}}$ value). Changes in concentration may be caused by the mechanisms associated with hydrolytic decomposition and higher temperatures during the long period of storage [17]. Weakly acidic or basic drugs show good solubility as a result of ionization and thus their degradation rate is faster. For the reconstituted samples, the $\mathrm{pH}$ decreases as the suspension ages across all the storage conditions and brands (Tables 3-5). The decrease in $\mathrm{pH}$ value is expected Cefpodoxime being an ester which readily hydrolysed in water to form carboxylic acid, though the acid produced is either poorly soluble or it exceed its solubility product thereby leading to product colour change or cloudiness [18]. This explains the colour changes earlier discussed.

Most disperse systems are stable over a $\mathrm{pH}$ range of 4-8. The $\mathrm{pH}$ of the sample decreases as the samples ages. Products " $\mathrm{A}$ " and "C" have similar $\mathrm{pH}$ variation, although the $\mathrm{pH}$ of product " $\mathrm{B}$ " (3.00) deviate from the standard $\mathrm{pH}$ range stated above as early as day 14 at elevated temperature while, the $\mathrm{pH}$ values of products " $\mathrm{A}$ " and "C" only deviated from the standard range on day 60 across the storage conditions. The three brands evaluated were banana flavoured and sweet to taste throughout the duration of the study for refrigerated and room temperature conditions while the taste turned sour on the $30^{\text {th }}$ day for all the brands at elevated temperature. Sour tastes rely on ion current to conduct the taste signal, thus stronger ionic taste. Recall that hydrolysis of Cefpodoxime lead to more ionic degradation products. Particle size has profound effect on the dissolution of a formulation. The bigger the particle size the lower the dissolution rate and the less intense the taste of the particle. The particle sizes for products " $\mathrm{A}$ " and " $\mathrm{C}$ " were similar and significantly smaller than that of product " $B$ " (Table 6). Within the first 30 days of this study all the reconstituted samples were of smooth and sticky texture with the exception of those kept in the refrigerator which is smooth. The increase in temperature at both room and elevated temperature might have increase the kinetic energy of the individual particles of the molecules, thereby leading to an increase in their rate of collision which resulted in the samples being sticky.

The allowed moisture content should not be more than $10 \%$, because higher moisture content may encourage the growth of 
Citation: Ebenezer TO, Chioma C, Omoegbe IM. Instability of Cefpodoxime Proxetil Oral Suspension at Different Temperature Storage Conditions. J Pharmaceu Pharmacol. 2017;5(1): 6 .

microorganisms and an increase in the rate of the drug hydrolysis. With exception of the samples stored in the refrigerator whose percentage moisture content were greater than the allowable percentage, other samples at room temperature and elevated temperature have percentage moisture content within the allowable percentage moisture content. As a result of this, fungal growths were observed on the inner cover of the samples kept in the refrigerator.

The frictional force in a loose powder can be measured using the maximum angle possible between the surface of a pile of powder and the horizontal plane (angle of repose, $\theta$ ). Powders with a low angle of repose flows freely and vice versa. This powder flow property is determined by both shape and particle size. For amenable particle shape, powders with size range of 250-2000 $\mu \mathrm{m}$ flows freely while powders with particle sizes $<100 \mu \mathrm{m}$ have flow problem. Angle of repose decreases as the sample ages with product $B$ having the lowest angle of repose at the elevated temperature (Table 5). This implies that since the particle size of product B is lowest angle of repose. The limitation of this study is that our experiments have thus far been conducted for three months rather than 6 months or one year, however the results for many of drug degradation/stability studies such as those examining the effect of physicochemical effect on the product shelf life shows similar results $[18,19]$. Our experiment, however, were designed to examine the effect of oral reconstitutable dry powder scenario rather than determination of product shelf life.

Our demonstration that elevated temperature do alter the physicochemical parameters of the oral reconstitutable Cefpodoxime proxetil adversely implies that patients should adhere strictly to the storage conditions specified by the producers of the evaluted Cefpodoxime brands in Nigerian market.

In summary our study shows that the physicochemical characteristics of the Cefpodoxime formulations is adversely affected at elevated above room temperature and by extension the product shelf life might be affected.

\section{Conclusion}

The purpose of stability testing is to provide evidence on how the quality of a drug substance or drug product varies with time under the influence of a variety of environmental factors, and it enables us to predict the storage condition, predict the period of time in which the product should be re-tested and finally determine the product shelf life. This research studied three brands of Cefpodoxime proxetil formulation (Products $\mathrm{A}, \mathrm{B}$ and $\mathrm{C}$ ) at potential temperature of exposures, which shows that the refrigerator temperature condition $\left(2{ }^{\circ} \mathrm{C}-8{ }^{\circ} \mathrm{C} / 40 \% \mathrm{Rh}\right)$ is best for storing the reconstituted suspensions and the non reconstituted samples is best stored a room temperature condition $\left(25^{\circ} \mathrm{C} / 60 \% \mathrm{Rh}\right)$. Product A showed a very good chemical, physicochemical and physical stability profile over time when compared with Product B and Product C. Thin layer chromatography show the presence of the degradation product after prolonged storage which underscores the importance of manufacturer instruction for storage and disposal of the product after usage. The increase in the absorbance of the reconstituted suspension after day 30 .

\section{References}

1. Banker GS, Rhodes CT (1986) Regulation of stability of marketed pharmaceuticals. Am J Pharm Educ 60: 224-228.

2. Allen LV, Popovic NG, Ansel HC (2011) Ansel's pharmaceutical dosage forms and drug delivery systems $\left(9^{\text {th }}\right.$ edn). Lippincott Williams \& Wilkins, Philadelphia, USA, pp. 489-500.

3. Kommanaboyina B, Rhodes CT (1999) Trends in stability testing, with Emphasis on Stability during Distribution and Storage. Drug Dev Ind Pharm 25: 857-868.

4. Geoffrey A, Milda S (1991) Clinical chemistry 37: 398-402.

5. Lachman CD, Lieberman AA (1995) The theory and practice of Industrial Pharmacy In ( $3^{\text {rd }}$ edn). Lea \& Febiger, Philadelphia, USA, pp. 207-215.

6. Sapna MM (2014) Seminar on dry syrup. Department of Pharmaceutics, University College of Pharmaceutical Sciences, Kakatiya University, Warangal, India, pp. 1-5.

7. Patel GC, Prajapati J, Morthana KM, Khunt DM (2015) Formulation and evaluation of oral reconstitutable suspension of Cefpodoxime proxetil. J Pharm Drug Dev 3: 2-8.

8. Siddalanga SMS, Shetty ASK, Anil Kumar SM (2012) UV-Visible spectrophotometric method for the estimation of Cefpodoxime proxetil in the bulk drug and pharmaceutical dosage form. Int J PharmTech Res 4: 750-756.

9. Bushra MU, Islam KR, Hossain MS, Sarah AH (2012) Method development and validation of Cefpodoxime proxetil in bulk and pharmaceutical formulation by using UV-Visible spectrophotometer. Ame J Pharm Tech Res 4: 817-824.

10. Abdel-fattah L, Weshahy SA, Hassan NY, Mostafa NM, Boltia SA (2015) Stability indicating methods for the determination of Cefpodoxime proxetil in the presence of its acid and alkaline degradation Products. Int J Pharm Biol Res 3: 223-239.

11. Achor M, Oyeniyi YJ, Yahaya A (2014) Extraction and characterization of microcrystalline Cellulose obtained from the back of the fruit of Lageriana siceraria (water gourd). J Applied Pharm Sci 4 : 057-060.

12. Sun J, Wang F, Sui Y, She Z, Zhai W, et al. (2012) Effect of particle size on solubility, dissolution rate, and oral bioavailability: evaluation using coenzyme Q10 as naked nanocrystals. Int J Nanomedicine 7: 5733-5744.

13. Bardeskar C, Geeverghese R (2015) Reconstitutable oral suspension (Dry syrups): An overview. World J Pharm Res 4: 462-484

14. United State Pharmacopoeia and Drug information (2009) Drug information for the health care professionals (volume 9) $\left(11^{\text {th }}\right.$ edn), Thompson Micromedex, Greenwood Village,USA, pp. 1-514

15. Mathew C, Ajitha M, Sathesh Babu PR (2013) Cefpodoxime Proxetil: A New Stability Indicating RP-HPLC Method. Chromatography 2013: 1-8.

16. Uzunovic A, Vranic E (2008) Stability of cefuroxime axetil oral suspension at different temperature storage conditions. Bosn J Basic Med Sci 8: 93-97.

17. Im-Emsap W, Paeratakul O, Siepmann J (2002) Disperse System. In: Gilbert SB, Christopher TR (Eds) Modern Pharmaceutics $\left(4^{\text {th }} e d n\right)$, Marcel Dekker, New York, USA, pp. 243-282.

18. Bajaj S, Singla D, Sakhuja N (2012) Stability testing of pharmaceutical products. J Applied Pharma Sci 02: 129-138.

19. Olaniyi A (2010) Principles of drug quality assurance and pharmaceutical analysis 9: 133-134. 